\title{
Kan daar iets oor God gesê word? 'n Perspektief vanuit die kritiese wysheid.
}

\author{
L C Bezuidenhout \\ Departement Bybelkunde (Afd A) \\ Universiteit van Pretoria
}

\begin{abstract}
Can something be said about God? A perspective from the critical wisdom

In the critical wisdom, traditional dogmata are scrutinised and proved to be unreliable. Yet, a new concept of 'theology' is proposed. The value of logic is appreciated, but its limits are accepted. Instead of conventional systematic thought, existential reflection is proposed.
\end{abstract}

\section{INLEIDING}

In die wysheidsboeke van die Ou Testament word daar op 'n besondere manier gekyk na die geldigheid van uitsprake oor God. 'n Mens merk 'n groot mate van relatiwiteit in die uitsprake oor God in boeke soos Job en Prediker. In hierdie artikel word gepoog om vanuit die perspektief van die kritiese wysheid te kyk na die moontlikheid van uitsprake oor God. Is daar enigiets wat sonder vrees vir teëspraak oor God gesê kan word? Sou so 'n belydenis kan aanspraak maak op absolute geldigheid? Is daar sekere dinge van God wat nie bevraagteken mag word of sekere dinge wat nie oor God gesê mag word nie? Kan 'n kritiese ingesteldheid met geloofsnailwiteit versoen word? Is daar binne radikale denke ruimte vir vertroue? Is uitsprake oor God van mekaar afhanklik in die sin dat 'n domino-effek ontstaan wanneer een uitspraak bevraagteken word?

Dit moet erken word dat wysheidsdenke en belydenis nie op dieselfde vlak funksioneer nie. In die eerste plek is wysheidsdenke nie noodwendig religieus nie, terwyl belydenis uit die aard van die saak religieus is. Tog word daar in beide genres gestreef na geldigheid. In albei is daar refleksie ten opsigte van die diepste dimensies van die werklikheid.

Hierdie is nie net 'n ondersoek na die moontlikheid van spreke oor God nie, maar ook 'n ondersoek na die 'milieu' waarbinne daar oor God gepraat word. Miskien is die 'milieu' belangriker as die uitsprake self.

Binne die wysheidgenre word daar gepoog om uitsprake te maak wat klop met die werklikheid. Schmid het in sy bekende boek Wesen und Geschichte der Weisheit (1966) aangetoon dat daar in die wysheid van die Ou Nabye Ooste 'n ontwikkeling 
plaasgevind het. In die wysheidsdenke van die Ou Nabye Ooste was dit normaal om in verskillende konkrete omstandighede uitsprake te maak wat mekaar inhoudelik weerspreek (vgl Schmid 1966:141). Hierdie soort relatiwiteit kan binne die wysheid geakkommodeer word aangesien uitsprake verband hou met die wisseling van omstandighede. Loader (1973:49) noem hierdie soort relatiwiteit relaxed relativity. Daar het in die wysheid 'n situasie ontwikkel waar die wysheid as 'n abstrakte sisteem van die werklikheid vervreem is en so dogmatiese geldigheid verkry. In hierdie sisteem neem die daad-gevolg-samehang 'n sentrale plek in. Wanneer besef word dat hierdie skema nie in alle opsigte geld nie, ontstaan die sogenaamde Krise der Weisheit (Schmid 1966: 131). Die wysheid kom teen die sisteem in opstand en vestig die aandag daarop dat die beginsel van kousaliteit (ten opsigte van daad en gevolg) nie altyd geldig is nie. Loader (1973:49) noem hierdie soort relatiwiteit tense relativity. In die Ou Testament verteenwoordig die boeke Job en Prediker hierdie fase, naamlik die kritiese wysheid (Loader 1973:53-56; Schmid 1966:173-196).

In hierdie artikel vorm die kritiese wysheid die lens waardeur gekyk word na die moontlikheid van spreke oor God.

\section{DIE MENS SE (ON)VERMOË OM IETS OOR GOD TE SË}

Alhoewel wysheid normaalweg geassosieer word met 'n logies-positiwistiese benadering, is daar tog in hierdie perspektief ruimte vir 'n openbaring.

\subsection{Die moontlikheid van 'n openbaring}

Elihu maak die volgende opmerking in Job 32:7-10 en 17-201:

Ek het gesê: Die dae sal praat,

baie jare sal wysheid bekend maak.

Dit is waarlik die gees in die mens,

die asem van die Almagtige wat hulle insig gee.

Maar die baie jare ${ }^{2}$ is nie wys

en bejaardes verstaan nie wat reg is nie.

Daarom sê ek: Luister na my -

ek sal my kennis bekend maak, ja ek sal.

Ek sal my deel antwoord, ja ek sal;

ek sal my kennis meedeel, ja ek sal;

want ek is vol woorde,

die gees binne-in my dring my. 
In teenstelling met die algemene opvatting oor wysheid, word die waarde van ervaring hier gerelativeer. Dit is nie 'n hoë ouderdom wat wysheid bring nie. Alhoewel hier nie pertinent van ' $n$ openbaring sprake is nie, is dit duidelik dat die Almagtige iets te doen het met wysheid.

Elifas het hom beroep op 'n openbaring wat hy van God gekry het (Job 4:12-17):

'n Woord het geheimsinnig na my toe gekom en my oor het die fluistering daarvan verneem

in die geestelike worstelinge van nagtelike gesigte wanneer diepe slaap op mense val.

Bewing en siddering het oor my gekom dit het my hele gebeente laat bewe.

'n Wind het voor my verbygegaan die hare op my vel het gerys.

Dit het gaan staan ... maar ek kon nie sien hoe dit lyk nie!

Daar was 'n gedaante voor my oë dit was stil - toe hoor ek 'n stem:

Kan ' $n$ mens regverdiger wees as God of ' $n$ man reiner wees as sy Maker?...

Elifas fundeer sy wysheid nie deur te wys na sy waarneming en logika nie. Hier het 'n openbaring plaasgevind. Die gedeelte het 'n konsentriese patroon. Aan die begin word gesê dat 'n woord na Elifas gekom het en dat hy dit gehoor het. Aan die einde word gesê dat die gestalte voor hom kom staan het en dat hy 'n stem gehoor het. In die middel word op twee maniere gesê dat hy bang was. Hierdie openbaring was van 'n mistieke aard. Die wind dien hier as metafoor van iets wat onbegryplik is.

Job twyfel aan die moontlikheid van 'n openbaring. Hy antwoord skepties op Elifas se mededeling (Job 9:11):

Kyk, Hy gaan by my verby sonder dat ek Hom sien. Hy sweef verby sonder dat ek dit bemerk. 
Job 9:16:

As ek Hom oproep en Hy my antwoord

glo ek nie dat Hy my stem sal hoor nie.

Hy sal my met 'n stormwind vernietig.

Hy sal my wonde vermeerder sonder rede.

In Elifas se gesig het ' $n$ wind by hom verbygegaan en God het wysheid aan hom openbaar. Volgens Job sal Hy nie eers opmerk as God by hom verbygaan nie. Indien God instem tot ' $n$ regsgeding, sal Hy nie eers luister na wat Job sê nie. Hy openbaar Hom nie in 'n wind nie, maar sal Job met 'n stormwind (בשערה) vernietig. Hy het immers Job se kinders met 'n groot wind vernietig (Job 1:19). Job word egter verkeerd bewys. Hy vind berusting nadat God Job ontmoet vanuit die stormwind (מן סערה - Job 38:1). Die ontknoping van die drama vind plaas in God se openbaring en nie in logiese dabatvoering nie.

Daar is die moontlikheid van 'n openbaring, maar elke aanspraak op 'n openbaring moet krities beoordeel word.

2.2 Weerverskynsels en die dimensies van die skepping as metafore om die onbegryplikheid van God se optrede uit te beeld

Dit is ironies dat juis die wysheid, wat daarna strewe om die werklikheid te deurskou, klem lê op die grense van die mens se begrip. Alhoewel daar reeds in die vroeër wysheid respek was vir die grense van die wysheid, word hierdie element in die kritiese wysheid op die spits gedryf. Onbegryplike en onvoorspelbare aspekte van God word uitgebeeld, onder andere deur die metafore van weerverskynsels en die onmeetlike dimensies van die skepping.

Elifas gee aan Job die volgende raad (Job 5:8-14):

As dit egter ek was, sou ek my tot God wend, ek sou my saak aan God opgedra het;

Hy wat groot en ondeurgrondelike dinge doen, wonders sonder getal;

Hy wat reën gee oor die aarde en water stuur oor die velde om die nederiges op te hef, ja, hulle wat rou, kry hulp; 
Hy wat die planne van slinkse mense verydel sodat hulle hande geen sukses behaal nie;

Hy wat die slim mense vang in hulle slinksheid

ja, die beraadslaging van die slinkse mense val plat.

In die dag kom hulle donkerte teë, in die middag tas hulle rond asof dit nag is.

Die reën word gebruik as voorbeeld van God se mag en sorg (vgl hoofstukke 36 en 38). Soos in die geval van die reën, het 'n mens nie beheer oor God se optrede nie. Tog kan jou gesindheid 'n invloed uitoefen op God se optrede.

Job verwyder hierdie element van optimisme. Hy stem saam dat God ondeurgrondelike dinge doen, maar glo dat God se optrede nie verband hou met die gesindheid van mense of kwaliteit van hulle lewens nie. Reën dien as voorbeeld van die onvoorspelbaarheid van God se optrede. Job beleef God se optrede voordurend as negatief. Hy lê klem op die vernietiging wat God bewerkstellig. God is nie net die oorsaak van orde nie, maar ook van chaos. Hy kelder ook die oordeel van mense (Job 12:14-25):

As Hy vernietig, word daar nie opgebou nie;

sluit Hy 'n mens in, word daar nie oopgemaak nie.

As Hy die water terughou, droog dit op,

laat $\mathrm{Hy}$ dit los, dolwe dit die aarde om.

By Hom is krag en sukses,

hy wat dwaal en hy wat laat dwaal, is syne.

Hy lei raadgewers kaalvoet weg;

Hy maak 'n gek van regters.

Hy maak die gordel van konings los

en Hy bind ' $n$ kleed om hulle lendene ${ }^{3}$.

Hy lei priester kaalvoet weg

en gevestigde mense bring Hy tot ' $\mathrm{n}$ val.

Hy ontneem die betroubares hulle spraak

en die oordeelsvermoë van die oudstes neem Hy weg.

Hy giet minagting oor edeles uit

en maak die gordel van die sterkes los. 
Job sluit hierby aan in 14:19:

Water skuur klippe,

stortvloede spoel die stof van die aarde weg,

so maak u die hoop van die mens tot niet.

In God se antwoord word die beeld van water weer opgehaal om God se optrede uit te beeld (Job 38:25-30):

Wie het vir die stortreën 'n kanaal gegrawe

en 'n pad vir die donderstorm

sodat dit reën op 'n land waar geen mens is nie

'n woestyn waarin daar niemand is nie

sodat dit verlatenheid en verlate land deurdrenk

en sodat dit vars grasspruitjies laat uitspruit.

Het die reën 'n vader

of wie gee geboorte aan die doudruppels?

Uit wie se moederskoot kom ys

en die ryp van die hemel, wie bring dit voort?

Asof dit ' $\mathrm{n}$ klip is, verberg die water homself

en sluit die oppervlakte van die watervloed aaneen.

Elihu het in 36:26-37:18 verwys na positiewe en negatiewe weerverskynsels. Volgens hom het die weerverskynsels ' $n$ spesifieke doel - of as seën of as straf. God sluit hierby aan in 38:22-24, maar in 25-27 blyk dit dat God se optrede nie gesien kan word as 'n reaksie op menslike optrede of behoeftes nie. In vers 27 word gesê dat God laat reën in 'n gebied waar geen mens woon nie. Selfs die woestyn kan blom. God skep omstandighede - Hy reageer nie net op omstandighede nie. Die grens tussen negatief en positief kan vervloei - water kan in ys verander. God bring voorspoed en teëspoed. Daar is egter die troos dat God grense aan die teëspoed stel. In die droogte bring Hy reën (Job 38:36-38):

Wie het die ibis $^{4}$ wysheid gegee

en wie het insig aan die haan 5 gegee?

Wie kan die wolke met wysheid tel

en wie kan die waterkruike van die hemel omkeer

wanneer die stof tot 'n gietwerk gegiet word

en die kluite aan mekaar kleef? 
Met treffende metafore beskryf Job die onbegryplike mag van God in Job 26:5-14:

Die skimme 6 bewe, die plek onder die see en hulle wat daarin is.

Naak lê die onderwêreld voor Hom, daar is geen bedekking vir die plek van verderf nie.

Hy span die noorde uit oor die leegte en hang die aarde op waar daar niks is nie.

$\mathrm{Hy}$ bind die water saam in sy wolke en die wolk skeur nie daarvan nie.

Hy bedek die troon 7 ,

Hy sprei 'n wolk daaroor uit.

Hy maak 'n sirkelvormige grens op die wateroppervlak -

'n grens tussen lig en donker.

Die pilare van die hemel skud, hulle bewe vanweë sy dreigende woede.

Deur sy krag bring $\mathrm{Hy}$ die see in beweging, deur sy insig 9 verpletter Hy Rahab

Sy wind ${ }^{10}$ maak die lug helder ${ }^{11}$,

sy hand verpletter die vinnige slang.

Hierdie dinge is ekstreme aspekte van sy dade.

Wat 'n fluistering hoor ons maar van Hom!

Wie kan die gedonder van sy magtige dade waarneem?

In Job 11:7-9 vergelyk Sofar die ondeurgrondelikheid van God met die dimensies van die aarde:

Kan jy die dieptes van God deurgrond

of kan jy reik tot die uiterstes van die Almagtige?

Dit is hemelhoogtes, wat kan jy doen?

Dit is dieper as die onderwêreld, wat weet jy?

In mate is dit langer as die aarde

en breër as die see. 
God sluit aan by hierdie beelde in Job 38:4-11:

Waar was jy toe Ek die aarde se fondamente gelê het?

Praat as jy insig het!

Wie het die mate daarvan vasgestel? Jy weet dit mos!

Of wie het die maatband daaroor uitgestrek?

Waarop is sy fondamentklippe ingesink

of wie het sy hoeksteen gelê

toe die môresterre saam gejuig het

en al die kinders van God gejuig het.

Wie het die see met deure ingeperk

toe hy uit die moederskoot uitgebars het

toe Ek die donderwolk bestem het om sy kleed te wees

en die donkerte sy doek.

Ek het my grens vir hom gestel 12

en 'n grendel en deure daar gestel.

Ek het gesê: Tot hier mag jy kom en nie verder nie

hier sal die trots van jou golwe aan 'n einde kom'13.

In verse 16-18 bou Hy hierop voort:

Het jy gekom tot by die bronne van die see

en het jy geloop in die diepte van die watervloed?

Is die poorte van die dood vir jou geopenbaar

en sien jy die poorte van die duisternis?

Omvat jou begrip die uitgestrektheid van die aarde?

Praat as jy dit alles weet!

Die dimensies van die aarde en see was vir die mens van ouds onbegryplik. So is die werk en plan van God vir die mens onbegryplik. In die skepping is die aspek van onbegryplikheid en die aspek van begryplikheid met mekaar verweef - soos ook in die geval van lewensvrae. Die metode van skepping is gedeeltelik logies. Die beeld van ' $n$ argitek en bouer word gebruik. Die proses van afmeet, fondasie uitgrawe en fondament lê, is logies. God konfronteer Job met die vraag: Waarop is sy fondamentklippe ingesink? Vir die mens van ouds was daar nie 'n antwoord nie. Die aarde funksioneer 
as simbool van sekuriteit, van lewensruimte. Dit is ironies dat die basis van hierdie sekuriteit nie vir die rede toeganklik is nie. So is die basis van sekerheid in die lewe ook nie vir die rede toeganklik nie.

Die teenwoordigheid van die see in die skepping is paradoksaal. Die see is simbool van chaos en bedreiging. Tog word dit as ' $n$ babatjie voorgestel wat deur God versorg word. Die blote bestaan van lyding is nie logies verklaarbaar nie, dit is vreemd dat daar ruimte vir lyding is in God se raadsplan. Tog kan 'n mens daarop reken dat God dit begrens en sodoende vir die mens te midde van lyding 'n leefruimte beskikbaar stel. Die diepte van lyding is onpeilbaar, maar so ook die uitgestrektheid van die lewensruimte.

In Job 28 word daar op 'n ander manier onderskei tussen ruimtelike dimensies. Hier word mynbou gebruik as metafoor vir die soeke na wysheid. Die mens slaag amper daarin om die dieptes te bereik wat volgens hoofstuk 38:17 nie vir die mens beskore is nie:

Is die poorte van die dood vir jou geopenbaar

en sien jy die poorte van die duisternis?

Volgens hoofstuk 28:3 slaag die mens daarin om diep in die aarde in te dring:

Hy maak 'n einde aan die duisternis

en hy ondersoek die diepste plekke

in die rots, donker en duister.

Uit hierdie dieptes haal die mens kosbare skatte. Tog vind hy nie die wysheid nie. Soos die dimensie van ondergrondse mynbou-aktiwiteite vir die dier verborge is, is die domein van die wysheid vir die mens ontoeganklik. Egte wysheid is net vir God beskore (Job 28:23-25):

God ken die weg daarheen

en Hy ken sy plek.

$\mathrm{Ja}$, Hy sien tot by die eindes van die aarde

en wat onder die ganse hemel is, bekyk Hy

met die doel om die gewig van die wind vas te stel

en die water met die maat af te meet. 
Die onbereikbaarheid van ware insig word voorgestel deur die onbeheerbaarheid en onbegryplikheid van wind en weer. God alleen het toegang daartoe. Die enigste weg vir die mens om naby ware wysheid te kom, loop nie deur die vlak van logika of waarneming nie. Dit kan alleen bereik word deur middel van 'n vroom lewe (Job 28:2628):

Toe Hy vir die reën 'n wet gemaak het en 'n pad vir die donderwolk, toe het Hy dit gesien en dit bepaal, Hy het dit vasgestel en dit deurgrond.

Maar vir die mens het Hy gesê:

Om die Here te vrees is wysheid en om die kwaad te vermy, is insig.

\subsection{Die mens se tydelikheid as begrensing van sy insig}

Die mens se tydelike bestaan dra by tot sy beperkings. In die boek Job verwys Bildad Job na die wysheid van die voorgeslagte. Volgens hom kan daar uit die wysheid van ouds vasgestel word dat God die regverdige seën en die onregverdige straf. Hierdie wysheid kan nie in die verloop van een geslag vasgestel word nie:

Jy moet navraag doen by die vroeëre geslag en let op die navorsing van hulle vaders, want ons is van gister en weet niks, ons dae is soos 'n skaduwee op die aarde.

Sal hulle jou nie leer en met jou praat en woorde uit hulle hart laat uitgaan nie? (Job 8:8-10)

God vra herhaaldelik in Job 38: 'Waar was jy toe ....' Met hierdie vraag impliseer God dat Job se lewe kort is en dat hy dus nie kan aanspraak maak op groot wysheid nie.

Spreuke 8 bevat wysheidsuitsprake uit die later tyd. Die wysheid word in 8:22-31 voorgestel as 'n buite-tydelike en buite-ruimtelike entiteit en geplaas binne 'n kosmologiese konteks (vgl McKane 1980:343-344, 351-358). Die mens kan hoegenaamd nie vergelyk word hiermee nie. Dit beklemtoon die kategoriese onderskeid tussen die mens en die verpersoonliking van wysheid.

Ook die Prediker verbind die verganklikheid van die mens en die beperktheid van sy kennis met mekaar (Pred 1:11): 
Daar is geen nagedagtenis van die voorvaders nie en ook van die geslagte wat kom

sal daar geen nagedagtenis wees

by die wat later sal wees nie.

In Prediker 3:1-9 word die mens se uitgelewerdheid aan die tyd beskryf. Die woorde wat hierop volg, is veelseggend:

Ek het die taak gesien wat God aan die mensekinders gegee het om hulle daarmee te kwel: Alles het $\mathrm{Hy}$ mooi gemaak op sy tyd; ook het Hy die ewigheid in hulle hart gelê sonder dat die mens die werk wat God doen, van begin tot end, kan uitvind.

(Prediker 3:10-11)

God het 'n verskeidenheid van omstandighede verschiedene Seinsweisen gemaak (Galling 1969:95). God het dit in die mens se denke geplaas om vrae te vra oor die verloop van alles. Tog is dit nie moontlik om dit te begrond nie. Alhoewel dit nie vir die rede vatbaar is nie, kan ' $n$ mens jou daaroor verwonder. God het alles mooi gemaak op sy tyd (Loader 1979:89).

\subsection{Aangryping as reaksie op God se optrede}

In die wysheidsliteratuur wat in hierdie artikel bestudeer is, is daar nuimte vir die element van verwondering. Die rasionaliteit van hierdie literatuur is nie 'n steriele harsingsgimnastiek nie. Die wese van hierdie literatuur lê nie in logiese beredenering en geldige konklusies nie. Die logika volg op belewing en kan dit wat beleef is, nie volledig omvat nie. Daar word tevergeefs gesoek na die 'boodskap' van hierdie literatuur asof dit ' $\mathrm{n}$ waarheid is wat in ' $\mathrm{n}$ neutedop saamgevat kan word. Die betekenis lê eerder in die besinging van dit wat beleef word. Daar kan skielik van 'n logiese redenering oorgegaan word na besinging van die geheimenisse (Von Rad 1970:144). In die kritiese wysheid, veral in die boek Job, word daar gestreef om te ontsnap uit die impasse van sisteemdenke. Die alternatief is nie volslae nihilisme nie, maar eerder 'n strewe om ontvanklik te wees vir nuwe ervaringe (vgl Von Rad 1970:143). Dit sluit aan by Salomo se bede in 1 Konings 3:9: 'Gee aan u kneg 'n horende hart' en die riglyn vir die regte optrede volgens Miga 6:8: 
... en wat vra die Here van jou

anders as die handhawing van reg, liefde en trou

en dat jy oplettend ${ }^{14}$ sal wandel saam met jou God.

God se antwoord aan Job vorm die klimaks van die boek Job (38:1-42:6). In hierdie ontknoping gaan dit nie oor logiese antwoorde op die vrae van Job nie, maar oor 'n ontmoeting met God en verwondering or sy skepping en sy raadsplan. Hierdie elemente kan nie van mekaar geskei word nie. Die verwondering is die ontmoeting en die verwondering oor die skepping is verwondering oor die raadsplan van God. Hierdie belewenis is veeldimensioneel. Hier word logiese wetmatigheid sowel as die onbegryplike en die paradoksale geakkommodeer.

Die waarheid lê nie in stellings wat oor God gemaak kan word nie, maar in 'n ontmoeting met God. In Job se verhaal het sy ontmoeting met God hom die volgende belydenis laat maak (Job 42:5-6):

\section{Volgens hoorsê het ek van U gehoor}

maar nou het my oog U gesien.

Daarom trek ek dit ${ }^{15}$ terug en verander ek my gesindheid in stof en as ${ }^{16}$.

\subsection{Die etiese aspek}

In bogenoemde uitspraak in Job 28:28 word die arena verskuif van die rasionele na die etiese:

Maar vir die mens het Hy gesê:

Om die Here te vrees is wysheid en om die kwaad te vermy, is insig.

Die etiese aspek van wysheid kom dikwels na vore in die uitspraak: Wysheid begin met die dien van die Here (vgl Ps 111:10; Spr 1:7; Spr 9:10). Die dien van die Here as sodanig is egter nie 'n bate nie. Prediker laat 'n waarskuwing hoor: In Prediker 4:17-5:6 word gewaarsku om nie te gou te praat of op te tree wanneer 'n mens met God te doen het nie. Dit is beter om liewers versigtig te wees en te luister. Tog gee hy die kategoriese bevel: Maar dien jy vir God (Pred 5:6)!

Die interpretasie van Spreuke 30:1-9 is problematies. Daar is egter elemente in hierdie gedeelte wat 'n sinvolle bydrae kan lewer tot hierdie onderwerp. In Spreuke 30 bely die digter sy onvermoë om iets oor God te sê: 
Ek is meer dier as mens.

Ek het nie die verstand van 'n mens nie.

Ek het nie wysheid geleer nie,

ek ken nie die heilige God nie.

Wie het na die hemel toe opgegaan en weer afgekom?

Wie het die wind in sy twee hande gevat?

Wie het die water in 'n doek toegedraai?

Wie het die grense van die aarde vasgestel?

Wat is sy naam

en wat is sy seun se naam

as jy dit weet?

(Spr 30:2-4)

In hierdie gedeelte kom motiewe voor wat ook in Job gebruik is. Dit is vir die mens onmoontik om eerstehandse kennis van God in te win. Daar is 'n groot afstand tussen God se domein en die mens se domein. God se onbegryplikheid word weer uitgebeeld deur middel van die beelde van reën, wind en die dimensies van die aarde.

Kan daar dan hoegenaamd iets oor God gesê word? In die volgende verse word dit bevestig. Die mens word egter weer vermaan tot versigtigheid:

Elke woord van God is gelouter,

Hy is 'n skild vir die wat by hom skuil.

Moet niks byvoeg by sy woorde

sodat Hy jou nie oordeel en jy as 'n leuenaar staan nie.

(Spr 30:5-6)

Hier is 'n kategoriese onderskeid tussen God se woorde en mense se woorde. God se woorde kan sonder voorbehoud aangeneem word. Hier is volgens McKane 'n persoon aan die woord wat deel is van 'n tradisie waarin die Joodse geskrifte bewaar en oorgelewer is. Waar verse 2-4 tuishoort by universele vrae oor kennis van god, is verse 56 die belydenis vanuit ' $n$ vroom tradisie (McKane 1970:643-644).

Daar bestaan geen eenstemmigheid onder kommentatore oor die eenheid van die eerste paar verse van Spreuke 30. nie $^{17}$. Daar is egter 'n moontlikheid om Spreuke 30:1-9 tog as 'n eenheid te lees, al word erken dat dit deur redaksionele ingryping tot stand gekom het. Die onderskeid in toonaard tussen verse 2-4 en 5-6 kan gesien word as fasette van ' $\mathrm{n}$ interne dialoog. Albei houdings is geldig. Daar is geen eerstehandse 
kennis van God nie. Tog kan 'n mens reken op God se belofte om beskerming te bied aan dié wat by Hom skuil. Daar is geborgenheid by God. Dit is deur God self aan die mens gekommunikeer. 'n Mens mag egter nie by hierdie mededeling jou eie wyshede oor God byvoeg nie.

Binne so 'n konteks maak verse 7-9 ook sin:

Twee dinge vra ek van $\mathrm{U}$;

moet dit nie van my onthou voordat ek sterf nie:

Hou valsheid en leuens ver van my af;

gee my nie armoede of rykdom nie -

laat my verskeur die brood wat vir my bestem is;

dat ek nie, as ek oorversadig geword het, $U$ verloën

en sê: 'Wie is die Here?' nie;

en dat ek nie, as ek arm word, steel

en my aan die naam van my God vergryp nie.

Die digter se lewe en strewe word bepaal deur sy verhouding met God. In sy kommunikasie wil hy hom nie eers aanmatig om bepaalde voordele van God te vra nie. Sy enigste wens is om in ' $n$ verhouding tot God te staan en nie iets te doen wat daardie verhouding skade sal aandoen nie. Hy bid nie vir 'n bepaalde vlak van welvaart nie (ook nie vir net genoeg kos soos die Nuwe Vertaling impliseer nie). Hy is tevrede met dit wat God vir hom bepaal het. Die enigste maatstaf wat hy wil aanlê om die regte porsie te bepaal, is die effek wat dit op sy verhouding met God het. Die porsie mag nie so wees dat dit sy verhouding met God skade aandoen nie.

Indien verse 2 tot 9 as 'n eenheid gelees word, kan 'n heropname van die metafoor van ' $n$ dier funksioneel wees. In vers 2 het die digter binne die konteks van wysheid gesê dat hy meer dier as mens is. Hiermee dui hy op sy beperkinge. In vers 8 vra hy dat hy die brood moet verskeur wat vir hom bestem is. Die werkwoord wat hier gebruik word, dui op die handeling van 'n roofdier wanneer dit sy prooi eet. In die konteks waar daar van ' $n$ mens se brood gepraat word, skep hierdie metafoor ' $n$ indruk van vervreemding. Tog kan dit 'n literêre strategie wees om 'n besondere effek te skep. Ongeag die aard van die porsie wat vir die digter bestem is, vra hy dat hy dit met oorgawe sal verorber. Indien die heropname van die metafoor van 'n dier in vers 8 teruggryp na die metafoor van ' $\mathrm{n}$ dier in vers 2 , is dit moontlik dat 'brood' in vers 8 ook verband hou met die 'porsie' wysheid wat vir die mens bestem is. Hierdie interpretasie is spekulatief, maar verdien verdere ondersoek.

Die digter se erkenning van die grense van sy insig asook sy naïewe berusting in God se beskerming herinner sterk aan die strekking van Psalm $131^{18}$ : 
Here, my hart is nie hoog

en my oë nie trots nie;

ook wandel ek nie in dinge wat te groot

of te wonderlik vir my is nie.

Ek het werklik myself tot bedaring gebring en stilgemaak

soos 'n (gespeende) kindjie by sy moeder

soos 'n (gespeende) kindjie is ek.

Wag op die Here, Israel,

van nou af tot in ewigheid!

(Psalm 131:1b-3)

In die kritiese wysheid word 'n hoë premie geplaas op die mens se verhouding met God (in Prediker val die klem anders). In die boek Job protesteer Job teen God, maar Hy spreek God telkens aan. Hy praat met God, al is dit op 'n onverantwoordelike manier. Sy vriende praat oor God op 'n verantwoordelike manier. Job is nader aan die waarheid as sy vriende. Die klimaks van die boek Job is juis die ontmoeting met God (hoofstukke 38-42:6).

\section{3. 'N MODERNE PARALLEL}

Daar is ' $n$ interessante ooreenkoms tussen die kritiese wysheid en die sogenaamde 'etiese rigting'. In Loader se artikel 'n Hervormde tradisie as heelmiddel (1996) kontrasteer hy 'n proposisionele waarheidsbeskouing met 'n 'etiese benadering', die benadering van die sogenaamde etici in Nederland gedurende die tweede helfte van die negentiende eeu en die eerste paar dekades van die twintigste eeu. Hy beskou laasgenoemde as 'n bruikbare teologiese benadering vir die Hervormde Kerk. Volgens die benadering word klem nie gelê op proposisies oor God en geloof nie, maar op 'n geloofsoorgawe aan God. Die woord 'eties' verwys na die strewe van hierdie teoloë om hulle te oriënteer aan wat hulle as die wese van die waarheid beskou het (Loader 1996:578). Die wese van die waarheid is dat dit in 'n lewende ontmoeting met God tot die mens kom en nie in proposisies nie (Becking 1995:144; vgl Loader 1996:578). Loader (1996:578-9) haal Velaton aan waar hy die etiese opvatting en die ortodoksie met mekaar vergelyk:

[H]ierin [ligt het verschil] dat men van ethischen kant nu ook voor de theologie as zoodanig van dit leven wil uitgaan, en de begrippen, d.i. de 
leer, daaraan subordineert ... [B] $]$ ij de ortodoxie: door de leer tot het leven; bij de ethische richting: door het leven tot de leer.

(Valeton 1904:10; vgl Loader 1966:579)

Vir Valeton dui die begrip 'lewe' op die geestelike ontmoeting met God (Valeton 1906: 9; vgl Loader 1996:579). Hierdie 'etiese rigting' sluit onder andere Daniël Chantepie de la Saussaye en J H Gunning jr in.

Loader skryf B Gemser en A van Selms se afkeer van dogmatisme toe aan die nawerking van hierdie rigting (Loader 1966:579; vgl Loader 1984:210-211).

Loader beskryf die plek van leerstellings in die etiese rigting soos volg:

Hoewel die dogmata alleen benaderings van God se waarheid kan wees, is hulle noodsaaklik .... Leerstellings is histories bepaalde proposisies wat wel op bepaalde tye in die verlede afgesluit is, maar vandag vir besinning en onderlinge begrip noodsaaklik is. Hieruit blyk dat proposisies onontbeerlik vir die teologie is, maar ook vir die kerklike geloofslewe. Hulle moet alleen maar nie verselfstandig word nie - wat gebeur wanneer hulle die objekte van geloof word in plaas van hulpmiddels vir die uitdrukking van die geloof. Die etiese begrip van waarheid as ontmoeting maak volledig voorsiening vir die belydenis in die vorm van proposisies ó́r die ontmoeting met God.

(Loader 1996:581)

Loader wys op die merkwaardige verband tussen hierdie denkrigting en die werk van Barth en Brunner (Loader 1996:583-584). Die volgende aanhaling van Brunner is veelseggend: 'Anders gesagt, der Glaube ist zwar, letztlich, nicht ein "etwas Denken", sondern personhafte Begegnung, Vertrauen, Gehorsam und Liebe’ (Brunner [1938] 1963:134).

Loader stel voor dat hierdie waarheidsbeskouing 'n positiewe bydrae kan lewer om die huidige verskille in die Hervormde Kerk te hanteer. Hy sluit af met ' $n$ aangepaste vertaling van Job 42:5: 'Volgens hoorsê het ek allerlei proposisies ór U gehoor, maar nou het my oog U self gesien' (Loader 1996:586).

Alhoewel Loader dit nie in sy artikel noem nie, is dit voor-die-hand-liggend dat sy jarelange studie van die Ou-Testamentiese wysheidsboeke 'n invloed op sy eie denke moes uitoefen. Dit het waarskynlik ook gegeld vir Gemser en Van Selms.

Gijsbert Bos gee 'n goeie bespreking van die werk van Gunning in sy publikasie Christus de gekruisigde voor en in ons: Gunning's getuienis van het verzoende leven 
(1981). Gunning se benadering kom kortliks op die volgende neer: 'Het etisch karakter der waarheid, haar bevat-zijn en geopenbaard-zijn in Jesus Christus, heeft ... tot noodzakelijk gevolg dat een mensch bekeerd moet zijn om de waarheid te kunnen verstaan (Bos 1981:129).

Die probleem met intellektuele sisteemdenke in die teologie is dat de zondaar van de nood een deugd maakt en de verschillende stelsels gebruikt om de afwezigheid van God niet meer zo pijnlijk te voelen. 'Hij had Hem immers in zijn denken, in zijn stelsel. Helaas! Het was niet meer het biddende: 'Gij zijt!' maar het redenerende: 'Hij is' (Bos 1981:128).'

\section{SLOTOPMERKING}

Die kritiese wysheid wil aandag vestig op die feit dat vertroue in sluitende denksisteme nie houdbaar is nie. Alhoewel mense hulleself probeer oriënteer deur middel van denksisteme, bring dit ' $n$ valse gerustheid en doen dit die waarheid geweld aan. Die kritiese wysheid verteenwoordig 'n fase van disoriëntasie. God, sy wil en sy optrede kan nie deur middel van sisteme begryp word nie. Hierdie fase van disoriëntasie is noodsaaklik met die oog op 'n re-oriëntasie.

Die kritiese wysheid kritiseer die valse optimisme in teologie. God kan nie in 'n sisteem ingepas word nie. In 'n sluitende sisteem is al die elemente op mekaar aangewese. Indien een aspek van die sisteem bevraagteken word, het dit 'n dominoeffek en die sisteem stort in duie. Hierdie aspek van sisteemdenke word dikwels gebruik om persone af te skrik om elemente van die sisteem in twyfel te trek.

Die kritiese wysheid wys daarop dat sekere elemente van die sisteem ongeldig is en dat die sisteem inderdaad in duie stort. Dit lei tot 'n re-oriëntasie: Waarheid is nie afhanklik van sisteme nie. Die kritiese wysheid baan die weg tot oorspronklikheid, kreatiwiteit, nuwe sensitiwiteit, oplettendheid en ontvanklikheid. In hierdie denkklimaat kan 'n nuwe 'teologie' ontwikkel. 'n Teologie waar die klem nie val op spreke oor God nie, maar op 'n verhouding met God.

In hierdie benadering is daar 'n verrassende varsheid en 'n egtheid. Alhoewel dit radikaal krities is, bied dit ruimte vir naïwiteit. Alhoewel dit klinies logies is, bied dit ruimte vir aangryping.

\section{Endnotas}

1 Vertalings van Job word geneem uit die proefskrif van L Bezuidenhout (1986).

2 Alhoewel die woord 'jare' nie hier voorkom nie, word dit veronderstel na analogie van die woorde 'baie jare sal wysheid bekend maak' in vers 7 .

3 Hulle status word weggeneem en hulle trek diensknegte se klere aan. 
4 Die betekenis van die woord תח is nie duidelik nie. Dit verwys waarskynlik na die ibis, die voël wat deur sy verskyning die styging van die Nyl aangekondig het (Fohrer 1963:509).

5 Die woord שכון het in die rabbynse taalgebruik die betekenis 'haan'. Die haan onderskei nie net tussen dag en nag nie, maar word waarskynlik ook in verband gebring met die reën (Fohrer 1963:509).

6 Die effek van God se skrikwekkende mag is selfs in die doderyk merkbaar (vgl Fohrer 1963:383).

${ }^{7}$ Die hemel word gesien as God se troon (Van Selms 1983:46).

8 Die vorm פרשו is waarskynlik 'n samevoeging van פרש e. פרש (Fohrer 1963:382).

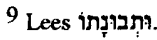

10 Die ב voor רוח word beskou as dittografie (Habel 1985:365; Van Selms 1983:48).

11 Lees שִָּּרָ as 'n pi'el (Habel 1985:365; Van Selms 1983:48).

12 Die interpretasie van die woord ו ו geïnterpreteer in die lig van die tweede versbeen (Habel 1985:521; Van Selms 1983:169).

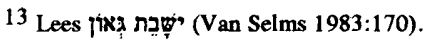

$14 \mathrm{Vgl}$ Van der Woude (1976:219).

15 Job trek sy saak teen God terug (Habel 1985:576). 'n Voorwerp word veronderstel vir die werkwoord oxp. Soos in 34:33 is Job se standpunt die voorwerp.

16 Job verander van gesindheid al is hy nog in stof en as, wat hier sy smart uitbeeld (Fohrer 1963:536).

17 Vir 'n bespreking oor die verskillende standpunte, kyk McKane (1970:643).

18 Hierdie psalm dateer waarskynlik uit die na-ballingskaptyd (vgl Kraus 1978:1052).

\section{Literatuurverwysings}

Becking, B E H J 1995. Valetons visie op het verbond: Gemeente-zijn in het perspektief van Jeremia 31:31-34, in Vlasblom, J \& an der Windt, J (reds), Heel de kerk: Enkele visies op de kerk binnen de 'Ethische Richting'. Zoetermeer: Boekencentrum. 
Bezuidenhout, L C 1986. Struktuur en strekking in die boek Job. DD-proefskrif. Universiteit van Pretoria.

Bos, G 1981. Christus de gekruisigde voor en in ons: Gunning's getuienis van het verzoende leven. Dordrecht: Uitgeverij J P van den Tol.

Brunner, E [1938] 1963. Wahrheit als Begegnung. Zürich: Zwingli-Verlag.

Fohrer, G 1963. Das Buch Hiob. KAT, Band XVI. Gütersloh: Gütersloher Verlagshaus Gerd Mohn.

Galling, K 1969. Der Prediker, in Die fünf Megillot. Tübingen: J C B Mohr (Paul Siebeck). (HAT.)

Habel, N C 1985. The book of Job. Londen: SCM. (OTL.)

Kraus, H-J 1978. Psalmen II. Neukirchen-Vluyn: Neukirchner Verlag. (Biblischer Kommentar Altes Testament Band XV/2.)

Loader, J A 1973. Relativity in Near Eastern wisdom, in Van Wyk, W C (ed), Studies in wisdom literature OTWSA 15 \& 18, 49-58.

- 1979. Polar structures in the book of Qohelet. Berlyn/New York: Walter de Gruyter.

1984. Die etiese Ou-Testamentici in Nederland tussen 1870 en 1914. ThDProefskrif, Universiteit van Suid-Afrika.

- 1996. 'n Hervormde tradisie as heelmiddel. HTS 4/52, 566-589.

McKane, W 1970. Proverbs. Londen: SCM. (OTL.)

Schmid, H H 1966. Wesen und Geschichte der Weisheit: Eine Untersuchung zur altorientalischen und israelitischen Weisheitsliteratur. Berlyn: Verlag Alfred Töpelmann. (Beihefte zur Zeitschrift für die alttestamentliche Wissenschaft.)

Valeton, J J P jr 1904. Etisch. Nijmegen: Ten Hoet.

Valeton, J J P jr 1906. Het Oude testament en 'de critiek'. Baarn: Hollandia.

Van der Woude, AS 1976. Micha. Nijkerk: GF Callenbach. (POT.)

Van Selms, A 1983. Job II. Nijkerk: GF Callenbach. (POT.)

Von Rad, G 1970. Weisheit in Israel. Neukirchen-Vluyn: Neukirchener Verlag. 